\title{
Duty of a Railway Company to Care for a Person It Has Without Fault Rendered Helpless
}

\begin{abstract}
VUPPOSE a passenger, an employee, or a trespasser is in$\infty$ jured by a railway train, under such circumstances that the company is not liable for the injury. Suppose further that he is so injured as to be unable to take care of himself and that if he does not receive immediate assistance death or severe permanent injury will result. Is the railway company liable if it neglects to give him the needed assistance? Is it liable if it undertakes to care for him, but does so negligently? If it is liable, is the doctrine peculiar to railways, or is anybody who without fault renders another helpless, liable for failure to minister to his immediate needs? It is the purpose of this article to attempt to answer these three questions.
\end{abstract}

\section{I.}

We will first consider whether the railway company is liable in the case of a passenger. That the company is liable if it negligently cares for a passenger injured without its fault goes without saying, because the company is not acting the good Samaritan when it cares for a passenger; it is merely fulfilling a duty growing out of the relation of passenger and carrier. ${ }^{1}$ That relation requires the railway company to remove an unattended sick or injured passenger and turn him over to somebody who can care for him. ${ }^{2}$ The company fails to fulfill that duty whether it neglects to remove the passenger or removes him negligently.

Yazoo \& U. V. R. Co. v. Byrd is a suit by a passenger who fell off a train through his own negligence. The railway left him lying near the track for more than three hours, when it could easily have taken him to a doctor at the next station. In affirming judgment for the plaintiff the court said:

"It matters not how negligent a passenger may have been in producing the injury for which he sues, it does not absolve the railroad from the duty which it owes to him of

110 C. J. 978, and cases there cited.

210 C. J. 900 and cases there cited.

8 (1906) 89 Miss. 308, 42 So. 286. 
proper attention after an accident shall have occurred, and if, when injured, the railroad company neglects this care, which common humanity would dictate, and by reason of the neglect, after the injury has occurred, a passenger suffers damage, he may recover against the railroad company for its dereliction."

The doctrine that the railway company is liable for failing to care for a passenger injured without its fault is, of course, peculiar to common carriers, for it is dependent upon the relation of carrier and passenger. But there are other relations somewhat similar to that of carrier and passenger to which the duty might be extended; for example, that of innkeeper and guest. In Scholl v. Belcher ${ }^{4}$ it was held to be the duty of an innkeeper to aid a guest who had been injured without his fault and was in a position requiring immediate attention, provided the innkeeper knew of the guest's need of assistance.

\section{II.}

We come next to the case of employees. A railway company is under the duty of furnishing emergency assistance to an injured employee, ${ }^{5}$ just as it is to an injured passenger. Because of the nature of the employment, the relation of employer and employee gives rise to this duty. Employment on a railway is not only hazardous, but it is migratory. The employee is likely to be injured not in his home town, where he has relatives, friends and credit, but far away, where if the railway employees do not care for him, he will die for lack of care. As stated in Cushman v. Cloverland Coal \& Mining Company: ${ }^{6}$

"The dictates of humanity cast upon the employer, as the one nearest in obligation, the duty to provide, during the continuance of the emergency, whatever is immediately and urgently required for the preservation of life and limb.

4 (1912) 63 Ore. 310, 127 Pac. 968.

5 Troutman's Adm'x. v. Louisville \& N. R. Co., (1918) 179 Ky. 145. 200 S. W. 488; Tippecanoe Loan \& Trust Co. v. Cleveland etc. Ry. Co. (1914) 57 Ind. App. 644, 104 N. E. 866, dictum; Slater v. Ill. Cent. R. Co., (1919) 209 Fed. 480; Ohio \& Miss. R. Co. v. Early, (1895) 141 Ind. 73,40 N. E. 257. See also the following cases holding that the highest employee on the spot has authority to hire a doctor to give emergency aid to an injured employee: Chicago \& A. $R . R$ v. Davis (1900) 94 IIl. App. 54; Terre Haute \& Ind. R. Co. v. McMurray (1884) 98 Ind. 358, 49 Am. Rep. 752; . Louisville, N. A. \& Co. Ry. Co. v. Smith (1889) 121 Ind. 353, 22 N. E. 775; Southern Ry. Co. v. Brister (1901) 79 Miss. 761, 31 So. 440; Adams v. Southern Ry. Co. (1899) 125 N. C. 565,34 S. E. 642,4 L. R. A. (N. S.) 63 , and cases there cited.

6 (1908) 170 Ind. 402,84 N. E. 759. 
Someone must serve the helpless man and the law devolves the duty upon the master rather than upon a stranger."

Or, as reasoned in Troutman's Ad'mx. v. Louisville \& $N$. R. Co. :

"The courts have also found much difficulty in settling on a ground on which to rest the liability of the master in cases like this where there is no contract or statute imposing the duty of taking care of an injured servant. We think, however, it may well be put upon the ground that, as it would be a cruel and inhumane act to leave a helpless servant injured in the course of his employment to suffer or die from want of care and attention there is an obligation growing out of the relation of master and servant that puts upon the master the duty of taking such reasonable care of the servant as the existing circumstances will permit."

Thus in the case of an employee as in that of a passenger, the duty to minister with due care to the necessities of the injured person, does not arise because the company assumed the burden of caring for him, but rather because the relation casts upon it the duty to act.

Is this doctrine peculiar to railways? It applies also to seamen, for they even more than railway employees are likely to be injured in places where they are dependent upon their employer for assistance. But are there not other industries to which it should apply? There are other industries as dangerous as railroading. A severely injured employee in a steel plant may be as much dependent upon aid from his fellow employees as a railway employee injured while crossing the deserts of Arizona. Thus there would seem to be no good reason for not extending the doctrine to cover all employments-certainly all dangerous employments. The weight of authority seems to extend the rule at least to other dangerous employments. ${ }^{9}$

7 Supra, n. 5.

84 L. R. A. (N. S.) 77; 35 Cyc. 1200.

9 Bessemer Land \& Improvement Co. v. Campbell, (1898) 121 Ala. 50, 25 So. 793, 77 Am. St. Rep. 17; Cushman v. Cloverland Coal \& Mining Co. (1908) 170 Ind. 402, 84 N. E. 759; Raasch v. Elite Laundry Co. (1906) 98 Minn. 357, 108 N. W. 477; Hunicke v. Meramec Quarry Co. (1914) 262 Mo. 560, 172 S. W. 43; Salter v. Nebraska Telephone Co. (1907) 79 Neb. 373, 112 N. W. 600; Stager v. Troy Laundry Co. (1901) 38 Ore. 480, 63 Pac. 645; Texas Bldg. Co. v. Drs. Albert and Edgar (1910) 57 Tex. Civ. App. 638, $123 \mathrm{~S}$. W. 716. See contra: Allen v. Hixson (1900) 111 Ga. 460, 36 S. E. 810; Godshaw v. J. N. Struck $\&$ Bro. (1900) $109 \mathrm{Ky}_{\text {. } 285,58}$ S. W. 781; Meisenbach v. Southern Cooperage Co. (1891) 45 Mo. App. 232. 
III.

Trespassers are the third class of persons we have to consider. The duty of active benevolence toward them cannot be made to depend upon the relation between the parties, because the only relation between the owners of a railway and trespassers on its property is that of fellow human beings. If the railway company is required to assist a trespasser whom it has rendered helpless without fault on its part, it must be because under such circumstances it is under legal duty to exercise benevolence toward human beings. But even if the law does not cast upon it that obligation, it may require the company, if it volunteers emergency assistance to the injured man, to exercise due care in giving it.

The leading case on both questions is Northern Central Ry. Co. v. State, Use of Price. ${ }^{10}$

In that case the deceased, a trespasser upon the property of the railway was run into by a train. $\mathrm{He}$ was mistaken for dead by the railway employees, who locked him in a warehouse overnight. During the night he regained consciousness, crawled a few feet and died of a hemorrhage. The action for wrongful death was in two counts, the first on the ground that the railway was liable for running into the deceased on the "last clear chance" doctrine, and the second on the ground that even if it were not, it was liable for failing properly to care for him. The court held there was sufficient evidence to sustain the verdict on both counts, saying:

"From whatever cause the collision occurrred, after the train was stopped the injured man was found upon the pilot of the engine in a helpless and insensible condition and it thereupon at once became the duty of the agents im charge of the train to remove him and to do it with a proper regard to his safety and the laws of humanity. And if in removing and locking up the unfortunate man, though apparently dead, negligence was committed, whereby the death was caused, there is no principle of reason or justice upon which the defendant can be exonerated from responsibility. To contend that the agents were not acting in the course of their employment in so removing and disposing of the party is to contend that the duty of the defendant extended no further than to have cast off by the wayside the helpless and apparently dead man, without taking care to ascertain whether he was dead or alive, or if alive, whether his life

10 (1868) 29 Md. 420, 96 Am. Dec. 545. 
could be saved by reasonable assistance timely rendered. For such a rule of restricted responsibility no authority has been produced, and we apprehend none can be found."

If the facts of this case only, and not the opinion of the court are considered, it might be possible to distinguish it on the ground that the injured trespasser was taken from the side of the track, a place where other more careful and kind hearted people might have seen him and ministered to his necessities, and locked in the warehouse where nobody could find or care for him.

If this is the correct explanation of the case, it is obvious that it stands for no new or disputed principle of law. For even if the priest and the Levite were under no obligation to act the Good Samaritan and could walk by on the other side of the road with immunity, so far as the law is concerned, it is clear that they could not throw the wounded Jew into a river to drown or into the bushes where the good Samaritan had no chance of seeing him without being legally answerable for his death. ${ }^{11}$

But this explanation has never been offered, though the case has often been criticised and in Massachusetts has even been stated to stand for nothing but "the last clear chance", doctrine. ${ }^{12}$ Further one cannot tell from the facts whether the unfortunate victim would have had a greater chance of life if left beside the railway tracks.

The problem did not again arise until 1901, when on the authority of the Price case alone was decided Dyche v. Vicksburg S. \& P. Ry. Co. ${ }^{13}$

In this case the railway company undertook to care for the injured trespasser, but cared for him negligently. In reversing a nonsuit, the court said:

"It is manifest, as we think, that the railroad company cannot be liable for the original injury of the father of appellant. Nevertheless, we think the jury should have been permitted to pass on the acts of the company in shipping this helpless man to Tullalah, and after they brought him back. Assuming the charge of Dyche as it did, it was charged with the duty of common humanity, and the jury

11 Adams v. Chicago Great Western R. Co. (1912) 156 Iowa 31, 135 N. W. 21; Weymire v. Wolfe (1879) 52 Iowa 533,3 N. W. 541 ; Depue v. Flateau (1907) 100 Minn. 299, 111 N. W. 1; 67 L. R. A. 516, note.

${ }_{12}$ Griswold v. Boston \& Maine R. R., (1903) 183 Mass. 434, 67

N. E. 354 .

13 (1901) 79 Miss. 361,30 So. 711. 
should have been allowed to pass upon whether or not it performed this duty."

New Orleans and N. E. Railway Co. v. Humphreys ${ }^{14}$ is a case of a trespasser discovered on the pilot of an engine with his leg shattered and in a helpless condition. Employees carried him into the station and called a physician. He asked the employees to carry him to Hattiesburg, his home, but they refused to do so, preferring to call a physician. Judginent on the verdict was given for the plaintiff, apparently on the ground that if he had been taken through to Hattiesburg on the train he was on instead of being taken off to await the physician, his leg would have been amputated two hours before it was and his chances of life would have been increased. The judgment for the plaintiff was reversed, the court saying:

"From our standpoint, the railroad employees did what was apparently the proper thing to do; and, even if they did not, there is nothing in their actions to authorize one to believe that they ignored the dictates of common humanity. In reversing this case we have assumed that the railroad company was under the duty to treat the trespasser with ordinary humanity, and, further, that it assumed charge of him when they took him from the locomotive. If a mistake was made, it was a mistake of judgment, and for this mistake the railroad is not liable."

The three cases just considered require the railway company, if it volunteers emergency assistance to an injured trespasser, to exercise due care in giving it. We shall next consider the two cases denying the liability of a railway for negligently caring for an injured trespasser. The following quotation is from one of them, Griswold v. Boston \& Maine R. R.15

"But there is another view of this case, which strikes at the foundation of the plaintiff's claim. Her counsel has referred us to no case which supports the proposition that, if a person is injured through no fault of a railroad company the latter owes a legal duty to the person injured to assist him. There is, of course, a moral duty, but in performing that duty the company is not liable if one of its servants does not use his best judgment in affording the necessary assistance. The case of Dyche v. Videsburg, Shreveport and Pacific R. R. 79 Miss. 361, 30 South. 711, proceeds upon the singular ground that if a railroad company, though not in fault in injuring a trespasser, assumes charge of him, 
there is imposed on it the duty of common humanity and whether it has performed this duty is a question for the jury. We cannot accede to the doctrine of this case. If it is law, no humane or gratuitous act could be done without subjecting the doer of it to an action on the ground that the defendant ought to have acted more quickly, or with more judgment. It is a doctrine which would allow an action against a good Samaritan and let a priest and a Levite go free."

The other case is Riley v. Gulf C. \& S. F. Ry. Co. ${ }^{16}$ In this case the Court reaches the same result as reached in the Massachusetts case and for the same reason; that it would be unjust to punish a man for acting negligently, when he was under no duty to act at all; but reaches it by laying down the rule that no employee has authority to assume the duty of caring for an injured trespasser without special authority.

The reasoning of the Massachusetts case sounds very plausible. In some cases the situation of the injured man undoubtedly is such that his only choice is between receiving the negligent attention offered by the railway company or being left to die unattended. But in many cases this is not so. The fact the railway company has undertaken to care for the injured man might prevent other people from offering their services. In none of the cases did it appear from the facts that if the railway company had not cared for the trespasser nobody else would. Unless it so appears the reasoning of the Massachusetts case falls down. The railway company by taking charge of the man, has, under the pretense of doing him a service, done him an injury. The situation is similar to that of a railway company which places a flagman at a crossing who negligently fails to signal to automobiles the approach of a train. In such a case ${ }^{17}$ the Massachusetts court holds that though there was no duty upon the company to place the flagman at the crossing, having undertaken to warn the public, it must do so.

Furthermore there is nothing anomalous in the situation that a man who was originally under no liability to act, becomes liable to exercise due care under the circumstances, if he does act. For example, if you ask me to keep your watch for you, I need not do so; but if I do, I must exercise due care to keep it safely. 
Thus we find that the cases are three to two in favor of requiring a railway company which undertakes to assist an injured trespasser to exercise due care under the circumstances in so doing.

But what sort of assistance may the railway company give? What the injured man needs is a surgeon. If there is near the place of the injury a hospital which will receive the injured trespasser without charge to the railway, the company may, of course, take him there, and when it has done so, it has fulfilled its duty toward him..$^{18}$ But in many cases the trespasser will not be injured near a free hospital and the surgeon will wish to be paid for attending him. In such a case must the railway company pay the surgeon's bill? Apparently it is not required to carry its active benevolence that far, ${ }^{19}$ but it may do so. The conductor, brakeman, or whoever is the highest official of the company present, has authority to bind the railway to pay for the surgeon's services, if he wishes to do so. ${ }^{20}$ Of course, if higher officials of the company later notify the surgeon that the company will not pay his bill, he cannot collect for services rendered after such notice. ${ }^{21}$

So far we have seen that a railway company is liable for failing to exercise ordinary care to administer to the absolute needs of passengers and employees whose unfortunate injuries it has produced, notwithstanding it may have been without fault in producing such injuries; and that in the case of trespassers the authorities are divided. We have seen also that the relations of carrier and passenger and employer and employee require the railway company to undertake to administer emergency aid to passengers and employees. We come next to the question whether it is under a similar duty to undertake the care of trespassers.

One of the two cases on the subject holds that the duty exists and the other that it does not. In Whitesides v. South-

${ }^{18}$ Baltimore \& Ohio R. R. Co. v. State, use Woodward, (1874) 41 Md. 268; Atchison, T. \& S. F. R. R. Co. v. Weber (1885) 33 Kansas 543, 6 Pac. 877.

19 Vandalia R. R. Co. v. Bryan (1915) 60 Ind. App. 223, 110 N. E. 218.

20 Bonnette v. St. Louis, I. M. \& S. Ry. Co. (1908) 87 Ark. 197, 112 S. W. 220; Vandalia R. R. Co. v. Bryan, supra, note 19; Kendall v. Louisville \& N. R. Co. (1903) 76 S. W. 376, (Ky); but see contra, Adams v. Southern R. R. Co. (1899) 125 N. C. 565, 34 S. E. 642; Wills v. International \& G. N. R. Co. (1906) 41 Tex. Civ. Ápp. 58, 92 S. W. 273.

21 Vandalia R. Co. v. Bryan supra, n. 19. 
ern Ry. Co., ${ }^{22}$ decided in North Carolina in 1901, a trespasser was hit by a train and thrown off a trestle in a helpless condition. The train did not stop and the decedent after lying on the ground for many hours died of exposure. The plaintiff was nonsuited in the lower court, but the judgment was reversed on appeal. The action was based on two grounds: first, that the defendant was negligent in running over the deceased; and second, that having hit him it was negligent in not stopping the train to see whether he was hurt, and in not looking after him if he were. The upper court held that there was no evidence on the first point, but that the second ought to have been left to the jury, saying:

"This is the turning point in the case, because, if the defendant knocked the intestate off the trestle, and knew it had done so, and went on without stopping to look after and care for him, especially on such a night as that, that was such negligence as would make the defendant liable for the result."

The other case is Union Pacific R. Co. v. Cappier. ${ }^{23}$ A trespasser was struck by a moving car and injured so severely that he died a few hours later. The railway employees did not at once undertake to care for hin. Judgment in the lower court was for the plaintiff on the ground that the raitway employees were negligent in not conning to his aid sooner. The upper court reversed the judgment, saying:

"After the trespasser on the track of a railway company has been injured in collision with a train, and the servants of the company have assumed to take charge of him, the duty arises to exercise such care in his treatment as the circumstances will allow. We are unable, however, to approve the doctrine that when the acts of a trespasser himself result in his injury, where his own negligent conduct alone is the cause, those in charge of the instrument which inflicts the hurt, being innocent of wrong doing, are nevertheless blainable in law if they neglect to administer to the sufferings of him whose wounds we might say were self-imposed."

Though these two seem to be the only cases, railway or otherwise, in which the question has been decided, there are cases showing how other courts would decide the question if it arose. The court which decided the Price case, for example, would unquestionably have held the railway coinpany liable if

22 (1901) 128 N. C. 229,38 S. E. 878.

23 (1903) 164 Kansas 202, 72 Pac. 281. 
it had not undertaken to care for the trespasser. The court in Dyche v. Vicksburg S. \& P. Ry. Co., on the other hand, rested its decision merely on the duty of one who has undertaken to assist another, to do so with due care. The cases which do not allow recovery when the railway negligently cares for the injured trespasser deny it on the theory that it would be unjust to hold the company liable for acting negligently when, if it were more inhumane and failed to act at all, it would escape liability. So it is improbable that at present many courts would follow Whitesides v. Southern Ry. Co. But may not more follow it in the future? Is it not possible that this case and the other cases with dicta on the duty of a railway to act according to the dictates of humanity are mere forerunners in an attempt to get away from the common law rule that there is no legal duty to act the good Samaritan?

There is undoubtedly sound reason in favor of the distinctions between the duties owed by a railway company to provide for the safety of passengers, employees and trespassers. But once the injury has occurred, should the duty to care for the injured person depend upon the relation? The courts say the duty arises because it would be inhumane to leave an injured passenger or employee to die for lack of care. But is it any less inhumane if the injured person is a trespasser? If public opinion would not make a distinction, the law should not.

Ten years ago, the late Dean Ames of the Harvard Law School in an article entitled "Law \& Morals"24 pointed out the difficulty of requiring active benevolence when there was no relation between the parties except that of fellow human beings without working great injustice in many cases. Nevertheless, he believed that the law ought to require one to act the good Samaritan in certain cases and that the difficulty of drawing the line was not insurmountable. He suggested that the legislatures of the various states enact that:

"One who fails to interfere to save another from impending death or great bodily harm, when he miglit do so with little or no inconvenience to himself, and the death or great bodily harm follows as a consequence of his inaction, shall be punished criminally and shall make compensation to the party injured or to his widow and children in case of death."

2422 Harvard Law Review 97. 
Similar suggestions have been made by Jeremy Bentham, ${ }^{25}$ and Edward Livingston ${ }^{28}$ and other legal writers. In Holland a person is required by law to act the good Samaritan in certain cases. By Art. 450 of the Dutch Penal Code:27

"He who, seeing another person suddenly threatened with the danger of death, omits to give or furnish him with assistance, which he can give or procure without any reasonable fear of danger for himself or others, is punished, if the death of the person in distress has resulted, with three months' imprisonment and fine."

The cases cited in this article, however, attack the problem from a somewhat different angle. They consider the duty of active benevolence, not of a mere passer-by like the good Samaritan, but of a man who has injured another under such circumstances that he is not legally responsible for the injury. Whatever one may think of the advisability of the law requiring a passer-by to act the good Samaritan, there should be no doubt of the desirability of the law demanding active benevolence from the person who caused the injury. Therefore it is submitted that it should be the duty of a person who injures another, regardless of liability for the injury and of whether there is any relation between the parties, to exercise due care under the circumstances to minister to the immediate necessities of the injured person, if that person is rendered by the injury incapable of caring for himself and if death or severe bodily injury is likely to occur if assistance is not given.

Such a rule would not be as broad as that suggested by Dean Ames, since it would not cover all situations in which good morals require a man to act the good Samaritan, but it would be a step in that direction. It would be broader than that of Dean Ames in requiring due care under the circumstances without regard to inconvenience to the person causing the injury. The cases in which it has been applied do not indicate that it would be difficult of enforcement or likely to cause injustice in practice. Further it would be merely enforcing universally a duty which we have seen several courts already require of railways.

Law School, University of Oregon.

Sam B. Warner.

251 Bentham's Complete Works, edition 1859, 164.

262 Complete Works of Edward Livingston on Criminal Jurisprudence 126-127.

${ }_{27} \mathrm{H}$. A. D. Phillips on Comparative Criminal Jurisprudence, Introduction, 5 . 